\begin{tabular}{|c|c|c|}
\hline & Int.J.Curr.Microbiol.App.Sci (2016) 5(8): 255-257 & \\
\hline & International Journal of Current Microbiology and Applied Sciences & \\
\hline & ISSN: 2319-7706 Volume 5 Number 8 (2016) pp. 255-257 & \\
\hline EXCELLENT & Journal homepage: http://www.ijcmas.com & \\
\hline PUBLISHERS & & www ijemas.ce \\
\hline
\end{tabular}

Review Article http://dx.doi.org/10.20546/ijcmas.2016.508.026

\title{
Role of Lactic Acid Bacteria (LAB) in Food Preservation
}

\author{
J. Hitendra*, B. D. Narotham Prasad, H. Gurumurthy and V. C. Suvarna \\ Department of Agriculture Microbiology, UAS, GKVK, Bengaluru, India \\ *Corresponding author
}

\begin{tabular}{|c|c|}
\hline & A $\mathbf{B} T R A C T$ \\
\hline $\begin{array}{l}\text { Lactic Acid } \\
\text { Bacteria (LAB), } \\
\text { Food } \\
\text { Preservation. }\end{array}$ & \multirow{3}{*}{$\begin{array}{l}\text { Lactic acid bacteria comprise an ecologically diverse group of microorganisms united by } \\
\text { formation of lactic acid as the primary metabolite of sugar metabolism. Deserving an attention } \\
\text { for its capabilities, this will discuss on the general description of lactic acid bacteria, genetics, } \\
\text { metabolism and its application to the industries. Bacterial antagonism has been recognized for } \\
\text { over a century but in recent years this phenomenon has received more scientific attention, } \\
\text { particularly in the use of various strains of lactic acid bacteria One important attribute of many } \\
\text { LAB is their ability to produce antimicrobial compounds called bacteriocins. In recent years } \\
\text { interest in these compounds has grown substantially due to their potential usefulness as natural } \\
\text { substitute for chemical food preservatives in the production of foods with enhanced shelf life } \\
\text { and / or safety. There is growing consumer awareness of the link between diet and health. } \\
\text { Recent scientific evidence supports the role of probiotic LAB in mediating many positive health } \\
\text { effects. Traditional probiotic dairy strains of lactic acid bacteria have a long history of safe use } \\
\text { and most strains are considered commensal microorganisms with no pathogenic potential. }\end{array}$} \\
\hline Article Info & \\
\hline $\begin{array}{l}\text { Accepted: } \\
\text { 12 July } 2016 \\
\text { Available Online: } \\
\text { 10 August } 2016\end{array}$ & \\
\hline
\end{tabular}

\section{Introduction}

Lactic acid bacteria (LAB) are microorganisms that have been used for centuries to prepare and improve storage of food and for ensiling of different crops for animal feed. Lactic acid bacteria were first described as milk-souring organisms, due to the sour milk that arose from their production of lactic acid. They are a relatively diverse group of bacteria, but related by a number of typical metabolic and physiological features. Generally the group consists of gram-positive bacteria, cocci or rods, that are non-sporulating, non-respiring and produce lactic acid as the major end product during fermentation of carbohydrates.

LAB are normally found in nutrient-rich environments. Even if they grow in a variety of habitats, they are fastidious and amongst others nutrients they require fermentable carbohydrates, amino acids, fatty acids, salts and vitamins for their growth (Björkroth \& Holzapfel, 2006). Historically, the core group comprises the genera Lactobacillus, Leuconostoc, Pediococcus and Streptococcus, but the main LAB genera important in foodtechnology also include Aerococcus, Carnobacterium, Lactococcus, Oenococcus, Tetragenococcus, Vagococcus and Weisella.

Lactic acid bacteria are commonly found in foods, including fermented meat, vegetables, fruits, beverages, dairy products, in the respiratory, intestinal and genital tracts of humans and animals, in sewage, and in plant materials (De Vuyst and Vandamme, 1994). 
Lactic acid bacteria are added to the food as cultures and are generally considered to be harmless or even have an advantage for human heath in United States, they are recorded as GRAS (Generally Regarded As Safe).

Lactic acid food fermentation are common in tropical climates as a low cost method of enhancing food quality, safety and shelf life. Indians discovered this method of souring and leavening cereals, legumes batters. Egyptians developed wheat bread leavened with yeast and Koreans and credited for the production of acid fermented vegetable.

Bio Preservation of foods using lactic acid bacteria also enhance the quality of food mainly due to the production of primary metabolite lactic acid, which results in decrease of $\mathrm{pH}$. Many lactic acid bacteria are capable of inhibiting the growth of wide variety of food spoilage organisms. Mechanisms exploited in preservation is their potency to produce inhibiting agent. The classic example of commercially successfully naturally produced Nisin.

Fermentation was among the first few methods of food conversion. Fermentation was due to the activity of non- toxic microorganisms. This might have developed when mankind started collecting and storing food. Lactic acid bacteria involved in food conversion for example milk undergoes an acid fermentation naturally, readily and the acid protects the milk from spoilage by undesirable microorganisms in the environment. Fermentation helps in reducing toxins and antinational factor. Fermentation enhances the nutrient availability in the product, B-complex, protein efficiency ratio, $\mathrm{Fe}$ solubility, enzymes, volume are increased. Many biochemical changes also take pace during fermentation, sugar and non protein nitrogen are released.
The common lactic acid food fermentation of India includes pickles, idli, Dosa, Gunpanga, Dahi, Srikhanda, Bhallae, Punjabi, woni, papadam, vada Dhoka Sinks, mesu, Gendruk, Jhord, soyrubadi, Soysauce, Ambai and Bona.

LAB can be regarded as homo- or heterofermentative, depending on how they ferment hexoses under non-limited growth conditions. The homofermentative LAB use the glycolysis (Embden-Meyerhof-Parnas) pathway, resulting in lactic acid as the main end product resulting in lactic acid, carbon dioxide and ethanol (or acetic acid) as the major end products. However, homo- and hetero fermentative LAB cannot be distinguished solely on their production of certain fermentation Hetero fermentative LAB use the 6-phosphogluconate/ phosphoketolase pathway (6-PG/PK) products.

Lactic acid bacteria are known to compete with other microbes by modifying the microenvironment by their metabolic end products. Besides lactic acid, bacteriocins and non-proteinaceous low molecular mass compounds (LMMC) are produced by LAB in foods and contribute to the antimicrobial effects of added LAB cultures. Benzoic acid, methylhydantoin and mevalonic acid lactone contribute to the microbicidal action of Lactobacillus plantarum (Niku et al., 1999), and reuterin and pyroglutamic acid to those of $L$. reuteri. These biologically active substances differ from bacteriocins since LMMCs display a wide spectrum of activity against both Gram-positive and Gramnegative bacteria and fungi.

Vaughan et al., (1994) examined LAB isolated from variety of foods and found that presence of LAB in fruits and vegetables is comparatively very low when compared with cheese, milk and meat. Isolated lactic 
acid bacteria have greater potential in inhibiting the spoilage causing bacteria. Moreover, growing public awareness about the use of pesticide, together with the development of resistant pathogens and possible toxicological risks has prompted the search for alternative approach. As LAB is plenty in plant and plant associated products, and moreover these LAB have GRAS (Generally Regarded As Safe) status by FAO, there is a scope for using LAB isolated from plant and plant associated products as biocontrol agent against phytopathogens.

\section{References}

Bjorkroth, J., Holzapfel, W.H. 2006. Genera Leuconostoc, Oenococcus and Weissella, In M. Dworkin, S. Falkow, E. Rosenberg, K.-. Schleifer, E. Stackebrandt (Eds.), The Prokaryotes,
Springer, New York, pp. 267-319.

De Vuyst, L., Vandamme, E.J. 1994. Nisin, lantibiotic produced by Lactococcus lactis subsp. lactis: properties, biosynthesis, fermentation and applications. In: De Vuyst L., Vandamme E.J. (eds), Bacteriocins of lactic acid bacteria. Blackie, London, pp. 151-221.

Niku-Paavola, M.L., Laitila, A., MatillaSandholm, T. and Haikara, A. 1999. New types of antimicrobial compounds produced by Lactobacillus plantarum. J. Appl. Microbiol., 86: 2935.

Vaughan, E.E., Capiio, E., Roarke, N.O. and Fritzgerad, 1994, Isolation from food source of lactic acid bacteria that produced antimicrobials. J. Appl. Bacteriol., 76: 118-123.

\section{How to cite this article:}

Hitendra, J., B.D. Narotham Prasad, Gurumurthy and Suvarna, H. 2016. Role of Lactic Acid Bacteria (LAB) in Food Preservation. Int.J.Curr.Microbiol.App.Sci. 5(8): 255-257. doi: http://dx.doi.org/10.20546/ijcmas.2016.508.026 